\title{
Assessment of landslide occurrences in Serra do Mar mountain range using kinematic analyses
}

\author{
Rodrigo Irineu Cerri ${ }^{1}$ (1) - Fábio Augusto Gomes Vieira Reis ${ }^{1} \cdot$ Marcelo Fischer Gramani $^{2} \cdot$ Vania Rosolen $^{3}$. \\ George Luiz Luvizotto ${ }^{3}$. Lucilia do Carmo Giordano ${ }^{1}$. Beatriz Marques Gabelini ${ }^{1}$
}

Received: 5 February 2018 / Accepted: 23 April 2018 / Published online: 28 April 2018

(c) Springer-Verlag GmbH Germany, part of Springer Nature 2018

\begin{abstract}
Due to its meteorological, geological and geomorphological settings, Brazilian's Atlantic coast have suffered severe landslide phenomena, particularly along the cost of São Paulo, Rio de Janeiro, and Santa Catarina states. Studies have shown that these processes are complex and triggered by several factors. However, within the study area, many landslide locations are placed on gneiss migmatitic terrain with pronounced geological discontinuities. The objective of this paper is to assess landslide occurrences in Serra do Mar (Caraguatatuba, SP) and investigate, by means of kinematic analysis, how they correlate with foliation and fractures present on the rocks. Kinematic analysis is used to investigate which discontinuities are more favorable to landslides occurrence and their relationship with slope directions. Structural information and kinematic data models are used to evaluate cause-effect relationship of landslide processes. Results show that dip slopes, with NE-SW direction, have greatest potential for the occurrence of planar landslides. On the other hand, anti-dip and cross-dip slopes have a greater potential to develop wedge landslides. Rock weathering and fluid flux along foliation planes can intensify mass movement. Such effect is also seen in residual soil, since they are able to preserve relict structures of the rock. This study contributes to a better understanding of how geological structures, preserved in tropical residual soils, influence shallow landslides.
\end{abstract}

Keywords Landslides · Geological structures $\cdot$ Serra do Mar $\cdot$ Slope stability $\cdot$ Kinematic analysis

\section{Introduction}

Landslides are one of the most destructive and lethal natural hazards (Clague and Stead 2012), since they are characterized by rapid gravity-driven downslope movements of land/ soil and organic material (Nieble and Guidicini 1984; Selby 1993; Clague and Stead 2012; Guerra et al. 2017). Landslides are influenced by several factors (Fernandes et al.

Rodrigo Irineu Cerri

roocerri@gmail.com

1 Department of Applied Geology, Institute of Geosciences and Exact Sciences, São Paulo State University (Unesp), 24A Avenue, 1515, Bela Vista, Rio Claro 16506-900, Brazil

2 Institute for Technology Research of São Paulo State (IPT), Prof. Almeida Prado Avenue, 532, Cidade Universitária, São Paulo 05508-901, Brazil

3 Department of Petrology and Metalogeny, Institute of Geosciences and Exact Sciences, São Paulo State University (Unesp), 24A Avenue, 1515, Bela Vista, Rio Claro 16506-900, Brazil
2004; Silva et al. 2016; Guerra et al. 2017), both natural (e.g. rain, topography, soil and weathering characteristics) and anthropogenic (e.g. deforestation, agriculture, urbanization) ones. Furthermore, landslides are common but not restricted to mountain regions and, regardless of the morphology, they are strongly controlled by water and geological discontinuities, such as joints, faults, foliations, compositional banding and schistosity (Clague and Stead 2012).

Shallow landslides are frequently triggered by highintensity and long duration rainfall events, as seepage water potentially increases the slope's load and pore pressures, which in turn decrease internal shear strength (Peruccacci et al. 2012; Borgomeo et al. 2014; Von Ruette et al. 2014). Geological discontinuities work as preferential landslide detachment planes (D'Amato Avanzi et al. 2004; Hoek and Bray 1981; Roering et al. 2005; Zêzere et al. 2005; Margielewski 2006), given that shear strength is weaker along them (Selby 1993; Brenner et al. 1997; Yamasaki and Chigira 2011). Consequently, discontinuities also control geometry and style of landslides (Sturzenegger and Stead 2009; Yamasaki and Chigira 2011; Borgomeo et al. 2014; Kojima 
et al. 2015; Park et al. 2016). On the other hand, the precipitation of some secondary minerals, such as Fe-oxides and hydroxides, can recover physical-mechanical properties of the rock previously reduced due to fracturing, improving the toughness and shear strength of the rock (Cuccuru et al. 2012).

Kinematic analysis, using stereographic projection is a widely used method to evaluate structurally controlled landslides, usually in rock massifs and rock slopes (e.g. Gokceoglu et al. 2000; Brückl 2001; Brideau et al. 2006; Gratchev et al. 2013; Vatanpour et al. 2014; Siddique et al. 2015; Smith 2015; Park et al. 2016), but also in deeply weathered slopes (e.g., Shuib et al. 2006). The method basically consists in plotting attitudes of the discontinuities and the slope on a stereonet to evaluate stability, considering also the friction angle (Park et al. 2016).

The southeastern coast of Brazil is characterized by a nearly continuous and extensive (ca. $1500 \mathrm{~km}$ long) mountain range, called Serra do Mar. Serra do Mar presents a general ENE orientation and is related to orogenic emplacement structures (Vieira and Gramani 2015). It is predominantly composed of Precambrian gneissic and granitic rocks, commonly intruded by Cretaceous basic rocks. The occurrence of Cretaceous basic rocks is restricted to few portions within the study area, where they occur in the form of dikes (usually up to $2 \mathrm{~m}$ thickness). Due to the local hot and humid climate, the long slopes of the Serra do Mar escarpments are deeply weathered and substantially prone to landslides (Cruz 2000; Lacerda and Silveira 1992), often evolving debris flows (Cruz 1974, IPT 1988).

Serra do Mar hosts numerous cities, industries, hydrocarbon refineries, pipelines, and roads. Therefore, the occurrence of landslides in this region is of considerable socioeconomic significance. Many studies have attempted to understand the dynamics of Serra do Mar landslides (e.g. Furian et al. 1999; Seluchi and Chou 2009; Vieira et al. 2010; Dias et al. 2016; Cerri et al. 2017). However, none of them investigated deeply the role of geological discontinuities, even though Serra do Mar presents a notorious structural control (e.g. straight-lined escarpments and saprolitic regoliths preserving original rock structures). To bridge this gap, this study employs kinematic analysis method to evaluate the existence of structural conditioners on landslides at a small catchment $\left(13.11 \mathrm{~km}^{2}\right)$ hit by a catastrophic event in 1967.

\section{Study area}

The study area is located in the Caraguatatuba municipality (Northern coast of São Paulo State, Fig. 1), more specifically in the Canivetal River Basin. Inserted on the Serra do Mar mountain range, it covers an escarpment area on the eastern margin of the Brazilian Highlands, which has been known to be the most landslide prone location in the region. Major landslides and debris flows occurred in 1967, when the region received an intense and uninterrupted rainfall of $586 \mathrm{~mm}$ in $48 \mathrm{~h}$, resulting in a catastrophic number of landslides and debris flows (IPT 1988).

The area is one of most humid regions of Brazil, has annual precipitation of 1784 to $2000 \mathrm{~mm}$ and annual average temperature of $27^{\circ} \mathrm{C}$ (Cruz 1974). The scarps and steep slopes are covered by dense rain forest vegetation (biome of Mata Atlântica) that is composed of three main formations: (1) lowland forest; (2) hillside forest (tall trees with discontinuous canopy); (3) altitude forest (existing from $1.100 \mathrm{~m}$ of altitude and lower than the hillside forest) (Veloso et al. 1991; Instituto Florestal 2007).

\section{Geological and geomorphological characterization}

Rocks from the Serra do Mar mountain range belong to the Neoproterozoic Ribeira Orogen, that is characterized by a very complex geological and geomorphological framework. Lithotypes that occur in the area are gneiss, migmatite, migmatitic gneiss, anfibolite, granite, schists and quartzite (Heilbron et al. 2004; Hasui et al. 2012). Two restrict bodies of Cretaceous basic rock can be found in the form of dyke in the study area. Canivetal River Basin is inserted in a gneissic and migmatitic gneiss domain and rocks have a well-marked gneissic foliation that is parallel to compositional layering (alternation of biotite + muscovite rich layers and quartz + feldspar rich layers).

The Ribeira Orogen has a predominantly NE-SW strike that is marked by the main gneissic foliation, shear zones and faults formed during the assembling of the Gondwana Supercontinent in the Neoproterozoic. As an example, a main geological structure is the Bertioga-Caraguatatuba Fault (Hasui et al. 1978, 2012; Chieregati et al. 1982; DNPM/CPRM 1991; Heilbron et al. 2004).

The study area presents scarps with steep slopes, isolated hills and a coastal flat land (Cruz 1974, 1975). The extension of Serra do Mar mountain range presents a great variety of geomorphological characteristics. Some sections are steeper and continuous, others are irregular and heterogeneous, reaching up the coastline. This variation is related to the occurrence of faults, complex shear zones and morphotectonic events linked to the genesis of the Atlantic Plateau during the Pleistocene and Miocene (Almeida 1974; Ponçano 1981; Chieregati et al. 1982; Ross and Moroz 1997; Vervloet and Ross 2012; Vieira and Gramani 2015).

The study area comprises two main geomorphological compartments: (1) Coastal Province, formed by scarps, with a width of approximately $3-5 \mathrm{~km}$ and elevations between 


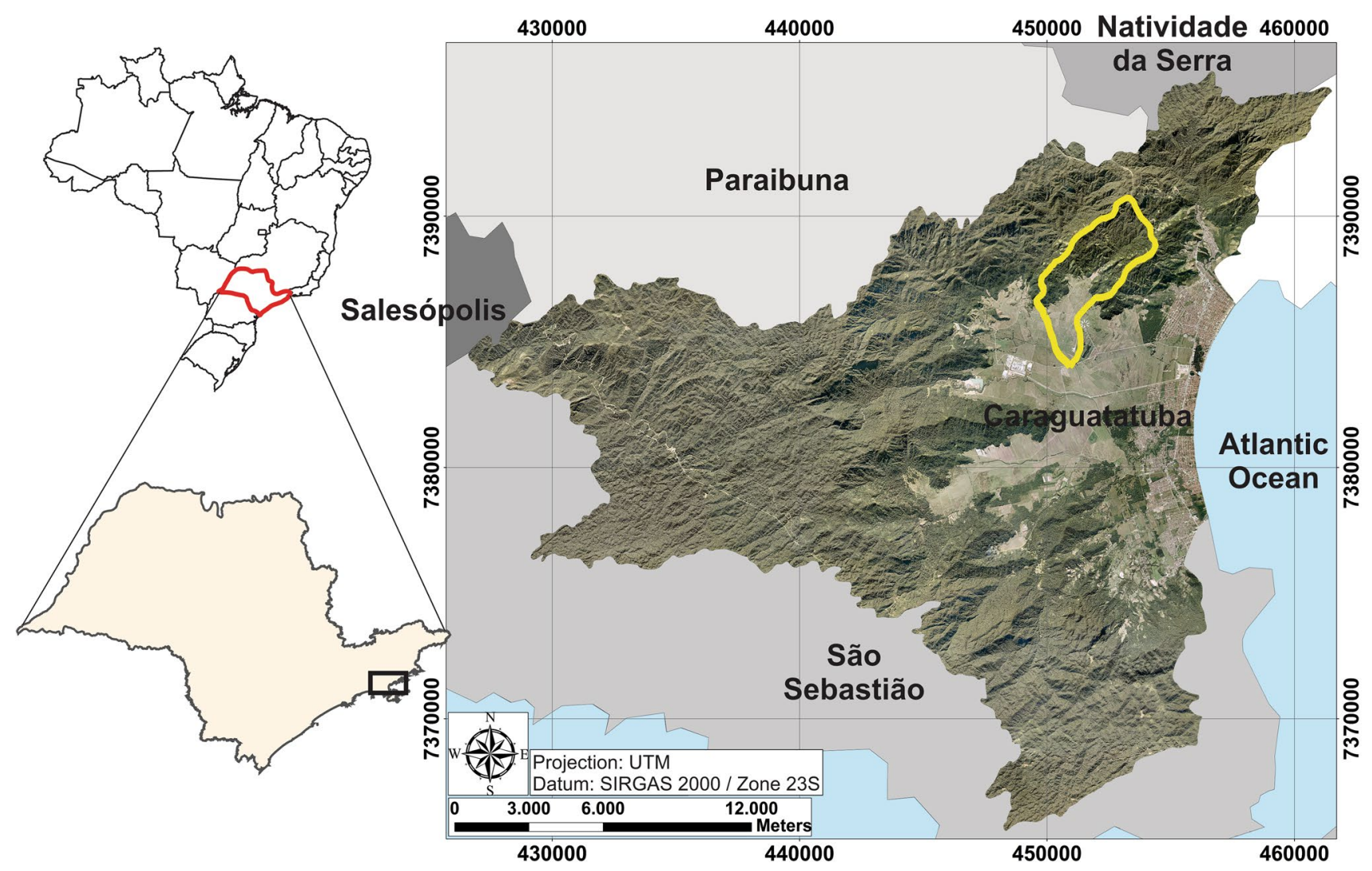

Fig. 1 Location map of the study area on the east coast of Brazil, in Caraguatatuba region. Canivetal River Basin is marked on yellow

800 and $1200 \mathrm{~m}$, and (2) flat area associated with a quaternary sedimentary flat land, with elevations from 0 to $10 \mathrm{~m}$.

\section{Data used and methodology}

Complementary maps were used to assess slope instability: (1) landslide locations, (2) declivity (to obtain the mean declivity of the studied slopes), (3) topographic (to obtain the dip direction of the studied slopes), (4) structural and geological maps (obtained from Hasui et al. (1978)). All the maps illustrated in this article use UTM SIRGAS 2000/ Zone 23S datum.

Landslide location map was extracted using the modification of vegetation patterns, texture, color and shape, using aerial photos ( $0.45 \mathrm{~m}$ resolution-stereoscopic techniques) and orthophotos ( $1 \mathrm{~m}$ resolution) in GIS software. Landslide locations are identified in Serra do Mar through the growth of fern (Gleichenia vegetal species). This specie adapts in thin soil areas, preserving the location of the landslides (Prado and Hirai 2011; Listo and Vieira 2015). Each landslide location was delimited as a polygon and then marked as a point on the center of each polygon.
Through the analysis of aerial photos (of 2011 with 1:20.000 scale) using stereoscopic methods, structural lineaments (joint and faults) and landslide locations were extracted. The structural lineaments were recognized based on drainage pattern (rectilinear and fitted drainages) (1544 structural lineaments were extracted). These geological structures are manifested in terrestrial surface as rectilinear traces, continuous or discontinuous, sometimes curvilinear, that can control the drainage pattern (Moura et al. 2012). After the structural lineaments interpretation, Kernel Density Algorithm Estimator (Parzen 1962) within output cell value of $10-10 \mathrm{~m}$ and search radius of 1500 , was used in ArcGIS 10.4 software to create a density map based on the structural lineaments. Density map was used to delimit regions with low or high concentration of geological structures (high or low fracture density).

\section{Kinematic analysis}

Kinematic Analysis was conducted using "Dips" computer code, from Rocscience platform (Rocscience 2010). This software generates kinematics analysis with three main parameters: (1) dip and dip direction of the slope, (2) dip and dip direction of the geological structures, (3) friction angle 
of the studied material. The software uses these parameters to generate a stereographic representation of the structural data and their relationship with the formation of wedge and planar sliding. The software shows a critical zone indicating the structure that can generate planar or wedge slides. Poles (planar sliding) or intersection points (wedge sliding) that are inserted in the critical zone have great potential to generate landslides processes.

Structural data were collected in the field, along drainages, erosions and small-road outcrops through the area. In total, 110 foliation planes and 431 fractures measurements were taken. Although most of the data was collected inside the Canivetal River Basin, some measurements were carried out outside the river basin to better constrain the structures.

Declivity and topographic maps were used to extract dip and dip direction of the slopes, respectively. Friction Angle values were obtained in the literature and are those for residual and saprolitic soils from gneiss/migmatite in tropical areas of Brazil (e.g., Bressani et al. 2001). The dense forest vegetation, high declivities, engineering construction covering up outcrops and the reduced number of access roads are the main problems that hinder a more detailed structural data acquisition.

For kinematic analysis, each slope was divided using a topographic map, taking into account the dip direction of the slope. In a first scenario, Canivetal River Basin slopes were divided considering each dip direction. In a second scenario, the northeast region slopes were divided in a more detailed way: any small variation of slope dip direction was considered important. This second scenario was conducted to generated bar graphs to analyze two main relations: (1) landslide locations and their relationship with declivity; (2) landslide locations and their relation to the slope dip direction. Thus, starting from a non-detailed slope division in Canivetal River Basin with kinematic analyses to generate a conceptual model, the relation of slope direction (in a detailed division), and the geological structures, were tested and confirmed for a larger area (northeast region).

\section{Results}

\section{Regional structure analysis}

Regional patterns of structural lineaments for the whole area are illustrated in Fig. 2. Structural lineaments have the same direction (NE-SW) as regional faults in the area (Camburu and Bertioga-Caraguatatuba Faults). Secondary fractures direction pattern (NW-SW) are also important and marked in aerial photos. Fractured regions are associated with unstable areas, well-marked by the great quantity of landslide locations.

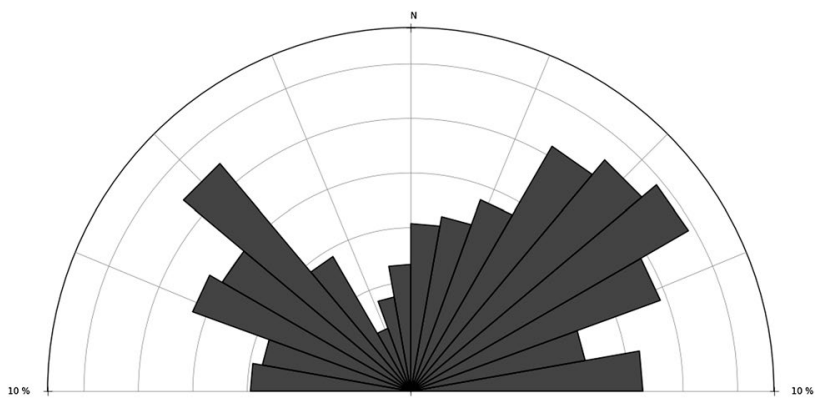

Fig. 2 Rose diagram of the frequency of the structural lineaments. NE-SW corresponds to the direction of the regional fault zones. 1544 structural lineaments were extracted with the aid of aerial photo

The northeast portion of the area shows a great number of landslides and structural lineaments: 333 landslides locations of a total of 436 (red color in Fig. 3), and 500 structural lineaments of a total of 1544 (high density in Fig. 3). Among the 500 structural lineaments, 302 lineaments are $2000 \mathrm{~m}$ distant from the Bertioga-Caraguatatuba Fault.

The major Bertioga-Caraguatatuba fault zone also has influence on the formation of deep structured valleys. The valleys orientated in NE-SW direction are controlled by this fault zone and other fractures zones with the same direction. They show rectilinear morphology and very deep and fitted valleys. Secondary fractures zones orientated in NW-SE have the same pattern, and influence the dynamic of some small and tributary rivers. The determined pattern of principal and secondary faults and fractures zones suggest that in the northeast region, geological structures have an important role in the geomorphologic evolution and relief modeling.

The Density of Structural Lineaments Map (Fig. 3) shows that northeast region has the highest density value, influenced by a regional fault zone (Bertioga-Caraguatatuba Fault). The landslides locations are concentrated in most part near Bertioga-Caraguatatuba Fault (281 landslides locations $2000 \mathrm{~m}$ away from the Bertioga-Caraguatatuba Fault), inserted in a geomorphological compartment composed of scarps with steep slopes in gneiss and migmatite with well-marked foliation and fractures patterns, both representing a setting which decreases slope stability.

In regional scale, the northeastern region is most susceptible for the occurrence of landslides. Inserted in the northeastern region, Canivetal River Basin has a great number of landslide locations, high density values of structural lineaments, slopes and valleys directly influenced by Bertioga-Caraguatatuba Fault.

Thus, more fractured regions influenced by major faults tend to have more landslides locations than other regions. Water infiltration and circulation is intense in highly fractured terrains, increasing weathering and slope instability, 


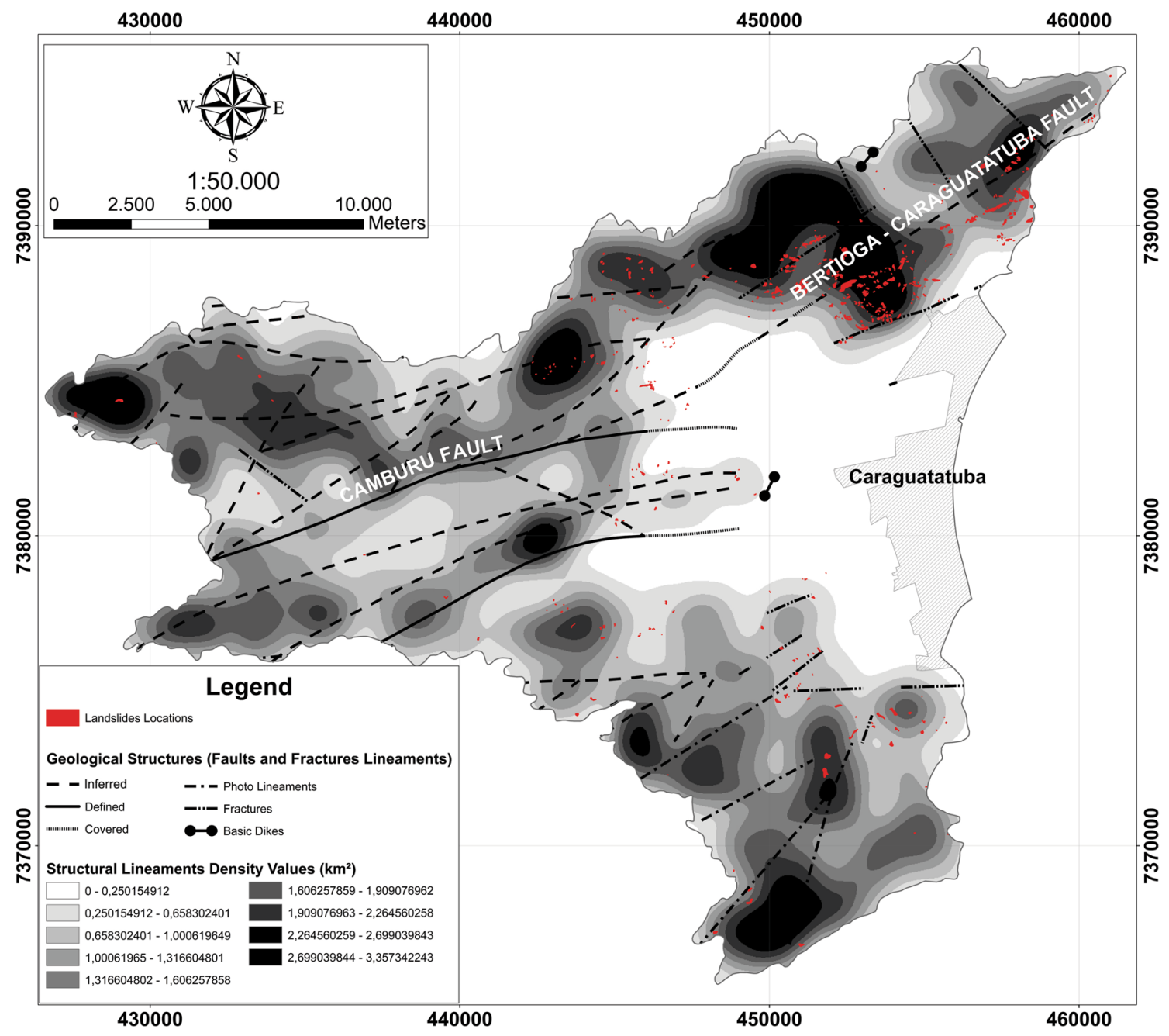

Fig. 3 Density of structural lineaments map showing the relation between density of fractures and the presence of landslide locations. The most fractured zone has the highest number of landslides location

justifying the high concentration of landslides in the northeast region (Moura et al. 2012).

\section{Structure and soil development in Canivetal River Basin}

Residual soils on Canivetal River Basin slopes are weathering products of gneiss, migmatitic gneiss, and migmatite. Field descriptions of residual soils presented in this article were carried out in exposures near or at landslide locations.

Residual soils profiles in Canivetal River Basin are generally composed of the following layers, from top to bottom: (i) superficial horizon (10-15 cm thick) composed of mineral and organic matter and roots; (ii) subsuperficial brown horizon (100 to $200 \mathrm{~cm}$ thick) silty sand; (iii) very fine saprolite (100-200 cm thick), clayey loam, with very fine sand and rare nucleus of weathered rock; (iv) fine saprolite of gneiss or migmatitic gneiss presenting nucleus of micaceous minerals surrounded by clay minerals, that often shows geological structures (fractures and foliation); (v) coarse saprolite preserving foliation (parallel to bedding) and fracture planes with the presence of kaolinite along the foliation plane, and (vi) unweathered, foliated, rock (Fig. 4).

Colluvial and talus deposits composed of sand, clay, and boulders of rock, can also occur, usually covering the bed rock and residual soils in the lower part of the slope. The influence of these relict structures (foliation and fractures) in residual/saprolitic soils are well known to influence the stability of slopes (e.g. Irfan and Wood 1988; Wiegand et al. 2013). Since not all the layers occur in a single soil profile, a representative weathering profile was compiled using several outcrops along the Canivetal River valley (Fig. 4).

Geological structures of the rock, such as joints, gneissic and migmatitic foliations and compositional banding are preserved in layers iv and $\mathrm{v}$ (fine and course saprolite). Well-developed soils (layers i, ii and iii) have maximum 


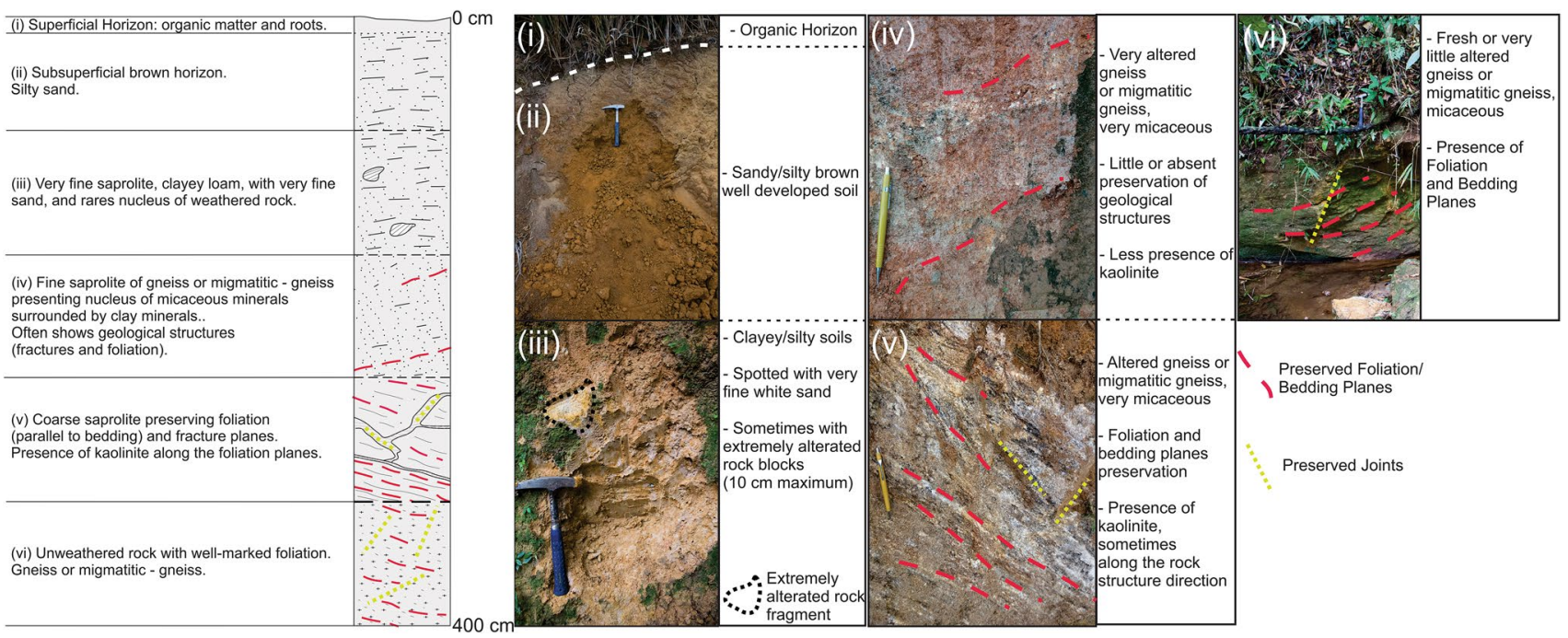

Fig. 4 Schematic, representative, weathering profile of the study area. The most common material in the area is the weathered gneiss and/ or migmatitic gneiss, with geological structures preserved. The pres-

thickness of $2 \mathrm{~m}$, while structured saprolite (layers iv and v), can reach up to $10 \mathrm{~m}$ in thickness (Wolle and Carvalho 1989; IPT 2000; Marcelino 2003; Vieira et al. 2010). The preservation of geological structures in residual soils makes a strong link between landslides in soils and the geological features of the source rock.

In the Canivetal River Basin, foliation is parallel to compositional banding in both gneiss and migmatite. Structures of the source rock are preserved even in residual soil layers where kaolinite and gibbsite minerals replace primary minerals (Furian et al. 1999). Presence of kaolinite along the preserved foliation planes has significant importance to slope stability. Kaolinite is an impermeable mineral, facilitating the horizontal/lateral water flow. This lateral flow controlled by kaolinite along foliation planes (impermeable layers) causes' preferential flow and consequently creation of a failure plane that can cause and/or initiate landslides processes (Furian et al. 1999).

The weathering profiles (isalteries) formed from gneiss, granite-gneiss and migmatite, preserves their petrographic textures, lithologic and tectonic structures (Modenesi and Toledo 1993). Isalterites present primary minerals that can be oriented, forming foliations or lineation, composing the skeleton (Modenesi and Toledo 1993). The plasma, characterized by secondary minerals (clay minerals, oxides and hydroxides), along with the skeleton and the porosity form a matrix. This matrix can preserve the original organization of the primary minerals in the form of kaolinite and/or gibbsite pseudomorph. In this way, geological discontinuities can be preserved by the growth of secondary minerals (gibbsite and kaolinite) or by the presence of residual primary minerals, such as micas. ence of kaolinite is also important and very present in the alteration profile. The sketch of weathering profile on the left side is not in scale

In the studied profiles (Fig. 4), the occurrence of biotite and muscovite along the foliation plane can change the friction angle of the residual soils, since these minerals are easily weathered. The lowest values of friction angle are observed in materials that have the highest quantity of micaceous minerals (Lacerda and Silveira 1992; Brenner et al. 1997; Souza Neto et al. 2001; Gobbi et al. 2005; Mendes 2008). Fe-oxides and hydroxides, that can increase rock toughness and shear strength, filling fractures or along the foliation planes were not observed in field analysis.

The value of internal friction angle adopted in this article is $28^{\circ}$ (Souza Pinto and Nader 1991; Bressani et al. 2001) and correspond to residual soils of gneiss with medium to high content of micaceous minerals with low fraction of clay and plasticity index.

\section{Geological structures in the Canivetal River Basin}

Other important feature to consider, beyond the residual soil characteristics and geological structures, is the fault zone architecture and structure permeability in brittle fault zones located in upper-crustal portions. Fault zones and their characteristics can create conduit, barrier or conduit-barrier permeability structures that control fluid flow (Caine et al. 1996). These authors consider fault material characteristics to correlate it to the porosity, permeability and fluid flow. Materials that lead permeability reduction, e.g., mineral precipitation and grain-size reduction are considered to be fluid flow barriers. Breccia, unconsolidated clay-rich gouge zones, cataclasite zones, high density of fracture, etc. can have high porosity and permeability, acting as a conduit to fluid flow. Fluid flow barriers can be responsible for locally 
increase of pore pressure in upper parts of the fault zone, inducing landslide occurrence.

Canivetal River Basin has an elliptical shape, characterized by a rectilinear channel controlled by Bertioga-Caraguatatuba Fault. The tributary drainages of Canivetal River are also controlled by fracture systems acquiring a rectilinear form, with NW-SE direction. The geomorphological setting of Canivetal River Basin can be seen in Table 1. Slope orientation of this river basin is predominantly NE-SW and is strongly controlled by the Bertioga-Caraguatatuba Fault. The foliation pattern of this region has a main NE-SW strike, dipping to NW or SE, with dip angles not exceeding $40^{\circ}$. Despite the existence of this fault, there is no change in the foliation pattern and there is no formation of secondary foliations linked to the formation of Bertioga-Caraguatatuba Fault in the Canivetal River Basin.

The geometrical setting presented above, with foliation, compositional banding and slopes having the same strike (dip slopes), can create slope instability. Figure 5 presents representative attitudes of foliation, studied outcrops, landslide locations and a schematic topographic profile (A-B), as well as the relation between the topography and geological structures.

The southeastern slope of Canivetal River Basin behaves like a dip slope, with higher mean declivity $\left(34^{\circ}\right)$ and higher amount of landslides locations (36 landslides location on the southeastern slope against 22 on the northwestern), when compared to the northwestern slope (anti-dip slope). Thus, dip slopes cause a decrease of stability and a greater probability of landslides occurrence.

\section{KINEMATIC ANALYSIS FOR CANIVETAL RIVER BASIN}

For planar landslides to occur, some main geometric conditions need to be satisfied (Wyllie and Mah 2004; Luzon et al. 2016): (1) the sliding plane must strike parallel or nearly parallel to the slope facet; (2) the sliding plane must have dip value less than the dip of the slope analyzed; (3) the dip of the slide plane should be greater than the value of the friction angle. For the occurrence of wedge landslides, two main geometric conditions have to be fulfilled (Wyllie and Mah 2004; Luzon et al. 2016): (1) the plunge of the intersection line between two discontinuities should be less steep than the declivity of the slope, and, (2) it should also be greater than the value of friction angle; (3) the intersection line must plunge out of the slope facet.

These geometrical conditions were considered to evaluate whether the discontinuities mapped in the area may generate planar or wedge landslides. Canivetal River Basin is divided into three main sectors for kinematic analysis with "Dips" computer code. The division is based in three main characteristics: (1) mean declivity, (2) slope direction and (3) dip direction of the slope. Table 2 shows the values of these parameters, and Fig. 6 shows the three delimited sectors. Structural data used for kinematic analysis considered only the structures within or adjacent to Canivetal River Basin (as can be seen in Fig. 6), where foliation has a predominantly NE-SW strike.

Foliation and fracture data were used in the kinematic analyses for all the segments, since all sectors are inserted in the same geological setting. It is important to highlight that the distribution of the foliation (parallel to compositional banding) and rock type is homogeneous through the Canivetal River Basin.

High declivity scarps occur in the highest part of sector 1. In aerial photographs, rock outcrops can be observed in the steeper portions of sector 1 . In sector 2 , rock outcrops are not present, and scarps occur in isolated areas and have little representation. This relief configuration shows that sector 1 has a shorter and steeper slope with more landslides locations than sector 2 .

Sector 1 (Fig. 7) presented 19 of the planes pole, for planar sliding kinematic analysis inserted in the critical zone $(17.27 \%)$. The main concentration of poles is very close to the critical zone, indicating the great possibility of planar sliding. It is important to highlight that a small decrease in the dip of the structures $\left(1^{\circ}-2^{\circ}\right)$ can bring more plane poles inside the critical zone. Foliation planes, with a $25^{\circ}-30^{\circ}$ dip angle and 320/330 dip direction behaves as a dip slope, increasing the potential to planar landslide occurrence. Thus, foliation planes with NE-SW direction, dipping to NW, could generate planar slides in sector 1 . Wedge sliding analysis leads to a total of 1038 intersections of planes (1.12\%) inserted in the critical zone. The wedge sliding analysis corresponds to wedges formed by three main plane families: 330/30 (foliation plane), 60/85 (fracture plane) and 248/80 (fracture plane). For wedge sliding, the main concentrations of intersection points are all well outside the critical zone,

Table 1 Characteristic of Canivetal River Basin, showing morphological parameters for this river basin

\begin{tabular}{|c|c|c|c|c|c|}
\hline Slope geometry & Declivity & Local amplitude & Valley form & River basin area & $\begin{array}{l}\text { Mean and maximum } \\
\text { declivity }\end{array}$ \\
\hline $\begin{array}{l}\text { Predominantly rectilinear } \\
\text { to concave }\end{array}$ & $15^{\circ}-45^{\circ}$ (medium to high) & $500 \mathrm{~m}$ & $\begin{array}{l}\text { Close and embedded } \\
\text { valleys }\end{array}$ & $13.11 \mathrm{~km}^{2}$ & $\begin{array}{l}24^{\circ} \\
88^{\circ}\end{array}$ \\
\hline
\end{tabular}




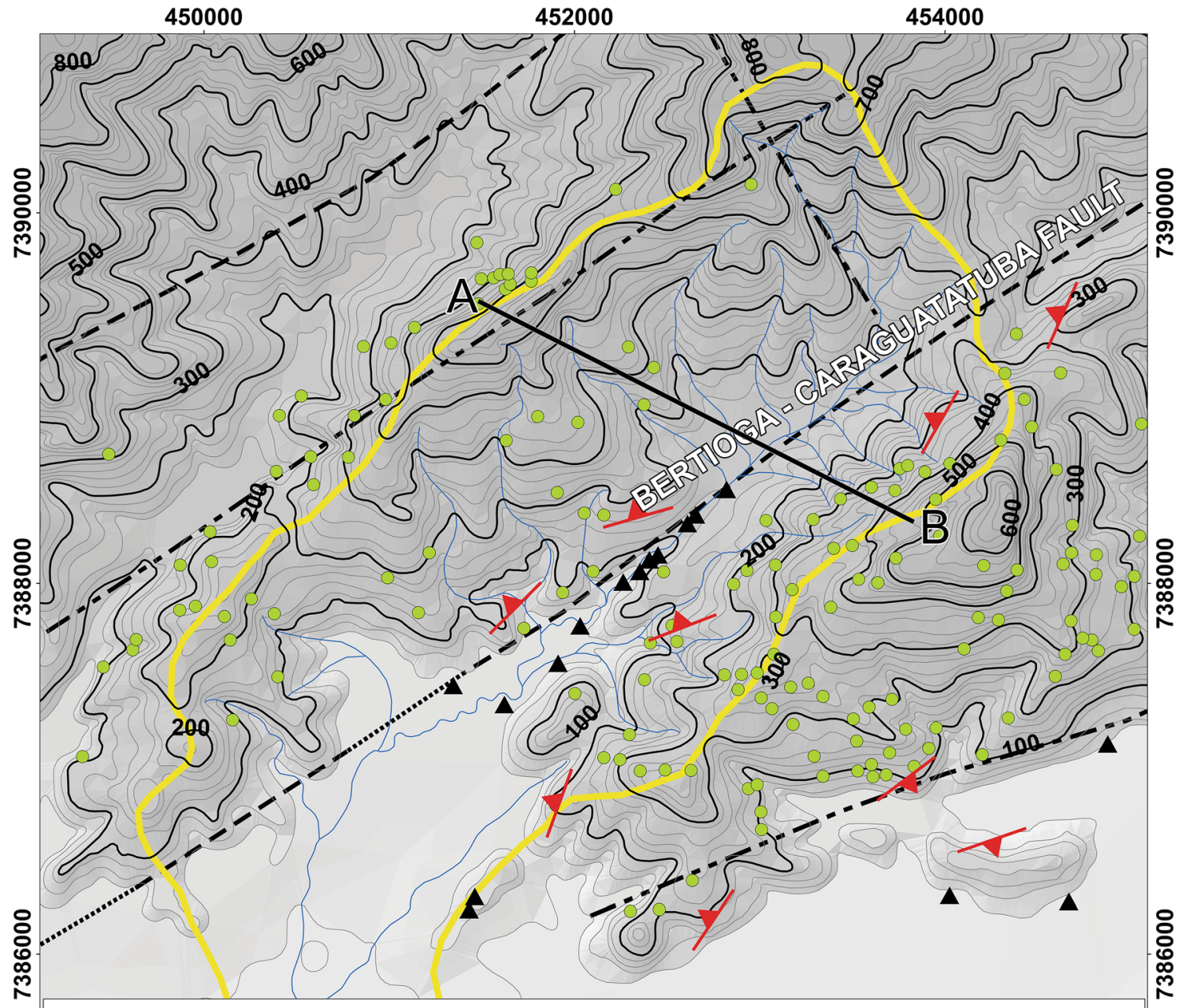

\section{Legend}

Structural Measures Structures and Faults
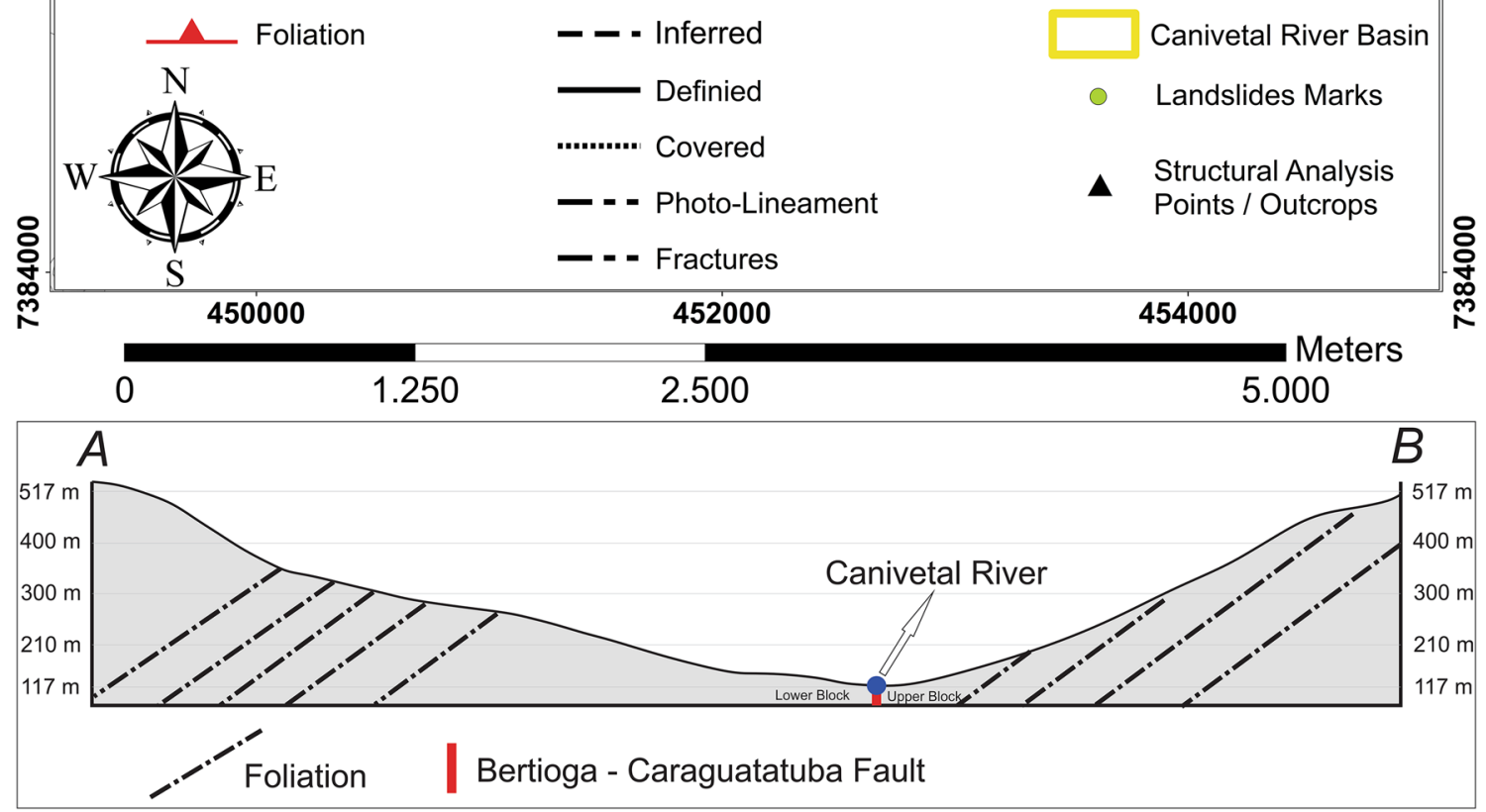
4Fig. 5 Canivetal River Basin showing principal foliation, landslide locations and its relation to the orientation and geometry of the slopes. Dip slope situation can be observed in the southeast slope of Canivetal River Basin. Projection UTM, datum SIRGAS 2000/Zone 23S. Equidistance of contour lines $=20 \mathrm{~m}$

indicating that wedge sliding can occur, but in a medium or low risk of occurrence of this phenomena.

Planar sliding analysis for Sector 2 (Fig. 7) shows that 2 poles are inserted in the critical zone $(1.82 \%)$. With a decrease of $9^{\circ}$ in the friction angle, 9 plane poles fall inside the critical zone $(8.18 \%)$. Therefore, the relationship between foliation planes and dip direction of the slope gains great importance for landslides analysis. The concentrations of poles (NW-SE dipping to SE) for planar sliding are near the critical zone, and the occurrence of planar landslides cannot be laid aside in this case. Analysis for wedge sliding had similar results as for sector 1, with 139 intersection points $(0.15 \%)$ inserted in the critical zone. Maximum concentration of intersection points in this sector fall outside the critical zone, indicating that wedge sliding can occur, but in a medium to low risk of this phenomena occurrence.

In Sector 3 (Fig. 7), no planar sliding is expected to occur according to the kinematic analysis. This sector has different direction compared to the foliation direction (cross-dip slope), with slopes dipping to SW. Thus, planar landslides controlled by foliation, for slopes with the same direction as the Sector 3, are not expected to occur. Wedge sliding analysis indicates that this sector has a greater potential to develop wedge landslides (1116 intersections on the critical zone-1.21\%). Nevertheless, the maximum concentration of intersections fall outside the critical zone, indicating that wedge sliding can occur, but in a medium to low risk of landslides occurrence.

Although landslides locations are not seen in photos from 2011, landslides events in sector 3 cannot be discarded. Landslides locations related to the 1967 event in Caraguatatuba, mapped by Fúlfaro et al. (1976), shows that there were 5 landslides inside sector 3 . Table 3 shows a resume of each sector and the probability of each type of sliding.

Stereonet from kinematic analysis for each sector is shown in Fig. 7. Landslides controlled by two discontinuities planes (wedge landslides) have more chances to occur

Table 2 Mean declivity, area, slope direction and dip direction of each sector analyzed in the kinematic analyses

\begin{tabular}{llll}
\hline Sectors & $\begin{array}{l}\text { Mean declivity } \\
\left(^{\circ}\right)\end{array}$ & Area $\left(\mathrm{m}^{2}\right)$ & $\begin{array}{l}\text { Slope direction } \\
\text { and dip direction }\end{array}$ \\
\hline 1 & 34 & 234,430 & NE-SW and NW \\
2 & 30 & 565,140 & NE-SW and SE \\
3 & 39 & 128,330 & NE-SE and SW \\
\hline
\end{tabular}

(sector 3, for example) when a cross-dip slope is observed. In sectors 1 and 2, wedge landslides can occur, but a dip slope situation can be observed, causing the occurrence of planar landslides to be more frequent.

Fracture and foliation data in Canivetal River Basin's adjacencies (Fig. 8) show that foliation has a main NE-SW strike (dipping both to NW, mainly, and SE, secondarily) with low dip angle (dip angles lower than $40^{\circ}$ ). Fractures (joints) have a main $\mathrm{N}-\mathrm{S}$ strike (five families of fractures), with high dip angle, always above $80^{\circ}$.

The regional setting of foliation suggests that hillslopes dipping to SE tend to be more unstable due to the parallelism with the foliation (dip slope, as can be seen in sector 1). The foliation dipping to SE has lower dip angle value than the foliations dipping to NW (Fig. 8a). Thus, sector 1 slopes have a higher dip value and a shorter slope distance, satisfying the geometric conditions, causing landslides to be controlled by the foliation.

\section{Discussion}

Kinematic analyses, focusing landslide type characterization are inexistent in Serra do Mar mountain range and in many other tropical mountainous areas with intense vegetation in Brazil. Detailed structural data become very difficult to acquire in such places and are key information to analyze landslides and their kinematics in this context.

The structural setting and lithological distribution are directly associated with landslides locations in the Canivetal River Basin. The structural lineaments, Bertioga-Caraguatatuba Fault and shear zones, well-developed foliation in gneiss and migmatite (parallel to layering), the micaceous nature of the rocks and the residual soils, are primary geological factors that can control landslides. Additionally, the structural control in residual soils due to the preservation of structures of the source rock as well as the presence of kaolinite along these planes can control landslides in Serra do Mar mountain range.

The main regional structure in the area is a NE-SW foliation, dipping either to NW or SE, in agreement with data presented by Campanha et al. (1994). This configuration, generating dip slope geometry, has great potentiality for the occurrence of planar landslide. This can be verified by kinematic analysis, where most occurrences of planar landslides are associated with dip slopes (sectors 1 and 2).

In adjacent areas, it was observed two main slopes in which planar landslides are controlled by foliation planes. In Fig. 9, a NW-SE section is presented to exemplify the relationship between foliation direction and slope geometry. In this portion, the main foliation still has a NE-SW strike, but with different dip direction: (1) either to NW; (2) or to 


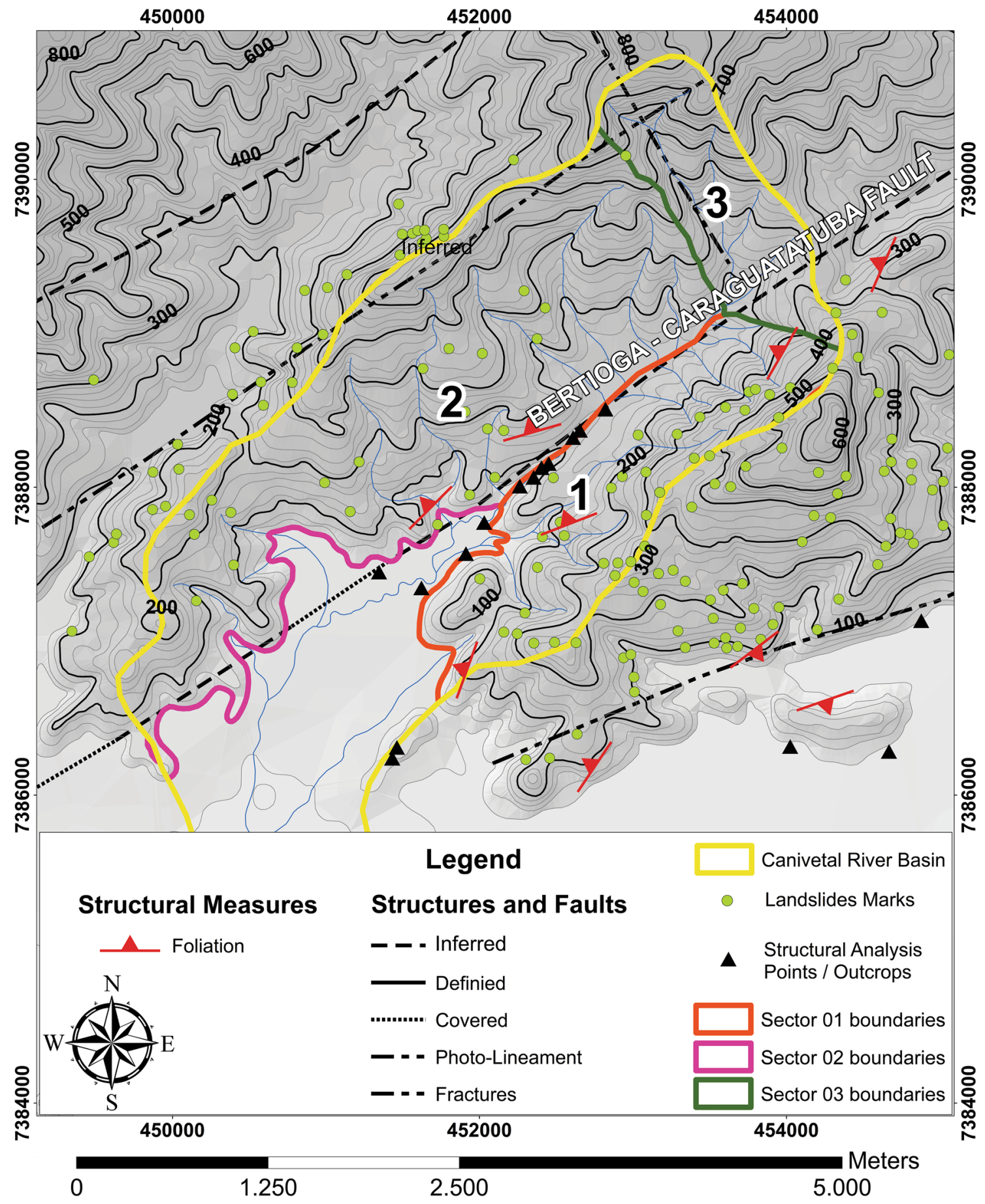

Fig. 6 Structural domains used to conduct the kinematic analyzes. Three main sectors were individualized due declivity, direction and inclination direction. The most representative structural measures are indicated in the map. Projection UTM, datum SIRGAS 2000/Zone 23S

SE. This local variation in foliation dip direction can influence the landslide type.

Landslide locations are more concentrated in dip slopes, when compared to anti-dip or cross-dip slopes. Local folding and change on foliation direction (Fig. 9) need to be detailed for landslides analysis. In this case, local change in foliation direction and local folding are locally influencing landslides kinematic analysis and controlling landslides occurrence.

For planar landslides (sector 1 and 2), the geometric condition between sliding plane and slope was satisfied: (1) the sliding plane has dip direction between N310 and N330, parallel or nearly parallel to the slope facet of sector 1 . For 
SECTOR 1
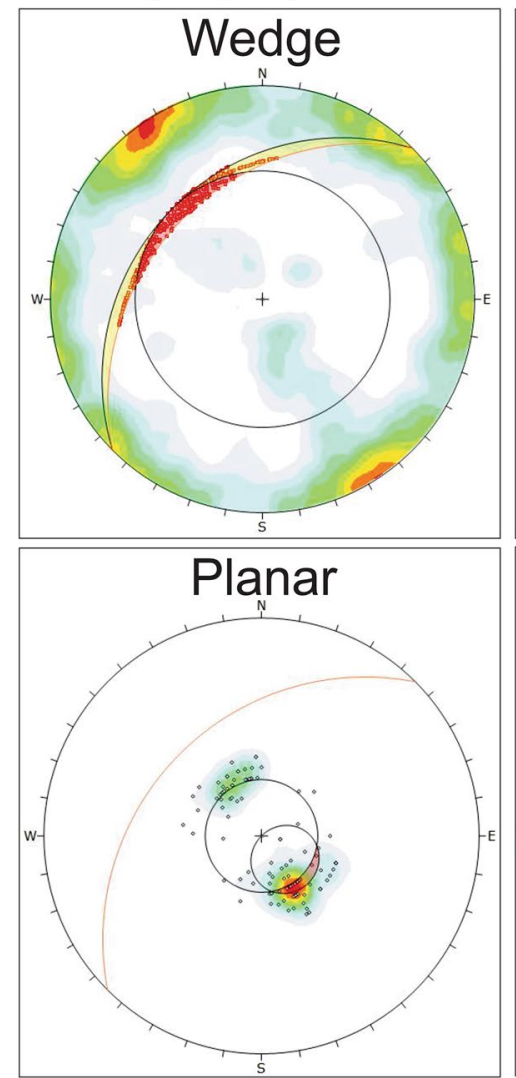

SECTOR 2
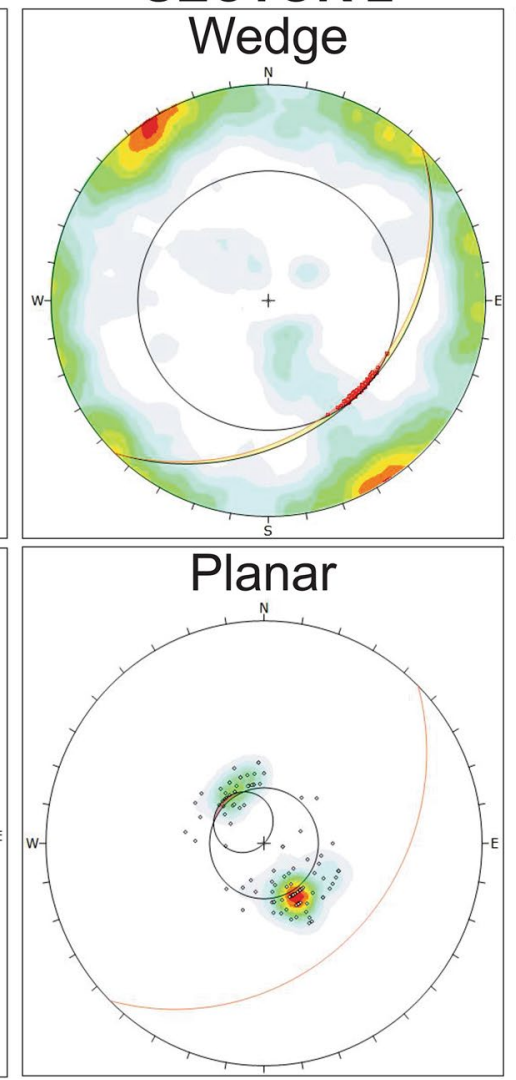

SECTOR 3

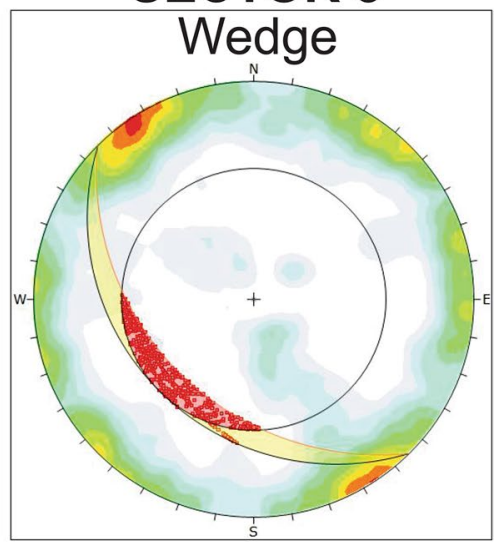

Fig. 7 Stereonet from kinematic analysis from each sector analyzed. Sectors 1 and 2 have potentiality for the occurrence of planar and wedge landslides. Sector 3, with divergent direction compared with foliation, has potentiality for occurrence of wedge landslides only

sector 2 , the concentration of foliation poles has dip direction between N150 and N130, almost parallel to the slope facet; (2) in these two sectors, the sliding planes have lower dip values $\left(25^{\circ}-30^{\circ}\right.$ for sector 1 , and $24^{\circ}-28^{\circ}$ for sector 2$)$ than the slope facet; (3) the dip of the sliding plane is greater than the value of friction angle, making planar landslides occurrence possible.

For wedge landslides, observed in all sectors, the geometric conditions were satisfied: (1) the plunge of the intersection line is less steep than the dip of the analyzed slope, and greater than the friction angle. For sector 1, 2 and 3, the dip

Table 3 Summary of kinematic analysis, indicating the type of movement and its probability

\begin{tabular}{lllll}
\hline Sector & $\begin{array}{l}\text { Slope dip } \\
\text { direction }\end{array}$ & Landslide type & $\begin{array}{l}\text { Probability for } \\
\text { planar sliding }\end{array}$ & $\begin{array}{l}\text { Probability for } \\
\text { wedge sliding }\end{array}$ \\
\hline 1 & NW & $\begin{array}{c}\text { Planar and } \\
\text { wedge } \\
\text { Planar and } \\
\text { wedge }\end{array}$ & High & Medium \\
2 & SE & Wedge & Very low & Low \\
3 & SW & Medium to high \\
\hline
\end{tabular}

of the sliding plane varies, respectively, between $28^{\circ}-31^{\circ}$, $28^{\circ}-29^{\circ}$ and $28^{\circ}-34^{\circ}$; (2) the intersection line dips out of the slope face, according to the intersection points observed and analyzed inside the critical zone during "Dips" software analysis.

In structural settings where gneissic foliation is parallel or nearly parallel with the slope facet, along with kaolinite, sliding planes can be generated. In weathered gneiss or migmatitic gneiss, the kaolinite (impermeable layer parallel to foliation) blocks vertical flow and starts a lateral water flow in porous layers (quartz-micaceous layers). After intense rainfall, preferential lateral water flow following preserved foliation plane marked by kaolinite, can generate failure plane with the same direction as the foliation, causing planar landslides.

Figure 10 shows diagrams with three different parameters for the northeast region of Caraguatatuba: (1) landslide locations versus declivity, (2) landslide locations versus slope dip direction, and (3) slope area versus slope dip direction. Northeast region consists of the most affected region by debris flow and landslides events in Caraguatatuba 1967. 
Landslides locations are almost concentrated in declivities about $16^{\circ}-25^{\circ}$ (Fig. 10a). Considering the dip direction of the slope (Fig. 10b), landslide locations are concentrated in slopes dipping to SE and NW. This configuration is also observed for the northeast region of Caraguatatuba city, where most of the landslide locations occur in dip slopes geometry. This analysis also agrees with kinematic analysis, where NE-SW slopes dipping to NW and SE have great potential for the occurrence of landslides controlled by planar discontinuities. Figure 10c shows the area of occurrence of each class of slope direction. Slopes with NE dip direction occupy less than $10 \%$ of the area, and have the greatest number of landslides locations. On the other hand, slopes with SE dip direction occupy almost $35 \%$ of the area and also have a great number of landslides locations.

The great majority of Brazilian researches related to landslides, attaches great importance to declivity values (e.g. Ramos et al. 2002; Carvalho and Riedel 2005; Lopes et al. 2007; Ferreira et al. 2008), and do not analyze geological structures as strong agents for landslide occurrence. Observing the data showed in Fig. 10 is possible to observe that landslides occur mainly on dip slopes, with a restricted spatial occurrence.

Landslides occurrence analyses cannot be supported only by declivity and geomorphologic data in hilly tropical regions with residual soils, although these factors are not negligible in Serra do Mar mountain range. An integrated study is the best way to understand landslides occurrence, and the preserved structures in the residuals soils seems to be closely related to landslide occurrence in tropical hilly regions.
Fig. 9 Section of slopes with two structural setting with landslide locations. Topographic profile shows slope A (in yellow) and slope B (in blue). Geological structures can control planar landslides in dip slopes. Projection UTM, datum SIRGAS 2000/Zone 23S

\section{Conclusions}

Preserved geological structures (foliations and joints) in residual soils, in humid tropical climate regions, such as Serra do Mar (north coast of São Paulo State), seems to be intimately connected with landslides control. These preserved structures are accompanied by the growth of kaolinite along the discontinuities. The junction between kaolinite growth and the discontinuities presence constitutes unstable surfaces with possible humidity concentration.

Kinematic analysis integrated with bar graphs of numbers of landslide locations versus slope dip direction shows that NE-SW slopes have great potential for the occurrence of planar landslides in the study area. Landslides in these slopes (dip slope geometry), dipping to NW and SE, parallel and sub-parallel to foliation planes, are controlled by preserved geological structures, causing planar landslides to occur. Wedge landslides can be observed in slopes with NE-SW direction and in different directions, according to kinematic analysis.

Canivetal River Basin has the same geomorphological configuration as the northeast region of Caraguatatuba city (larger area with hilly relief and controlled by faults and structural lineaments). This study indicated that landslides occur mostly on dip slopes with NE-SW direction. Wedge landslides occurrence are more prone to occur in slopes with NW-SE direction (cross-dip slope), but can also occur (with

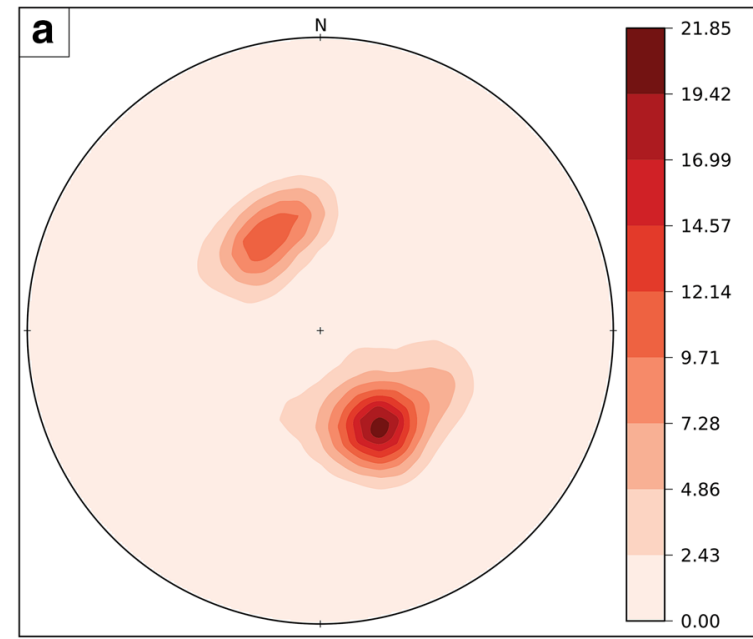

Fig. 8 Stereonet showing foliation (a) (maximum of 330/32 and 151/30) and fractures (b) (maximum of 141/82 and 327/84). Foliation have main direction of NE-SW, total of 110 entries. Fractures

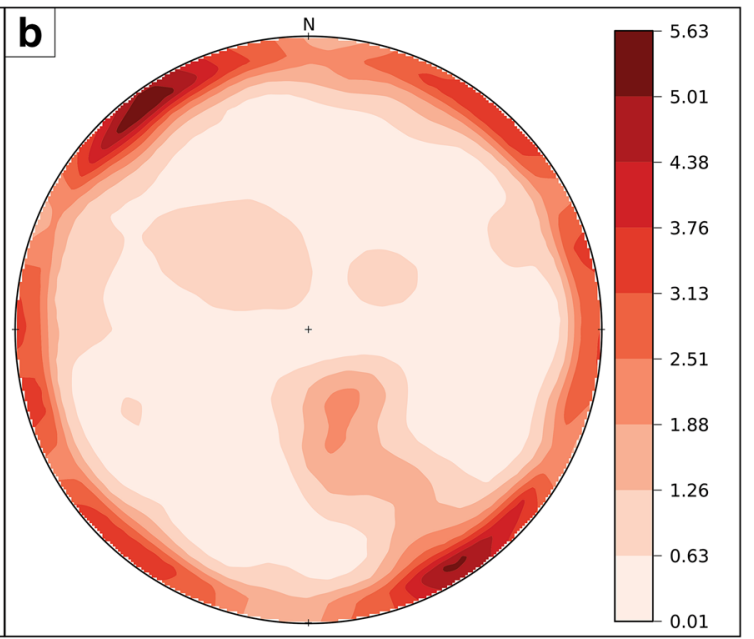

have main direction of NNE-SSW, total of 431 entries. Equal-area and lower hemisphere 

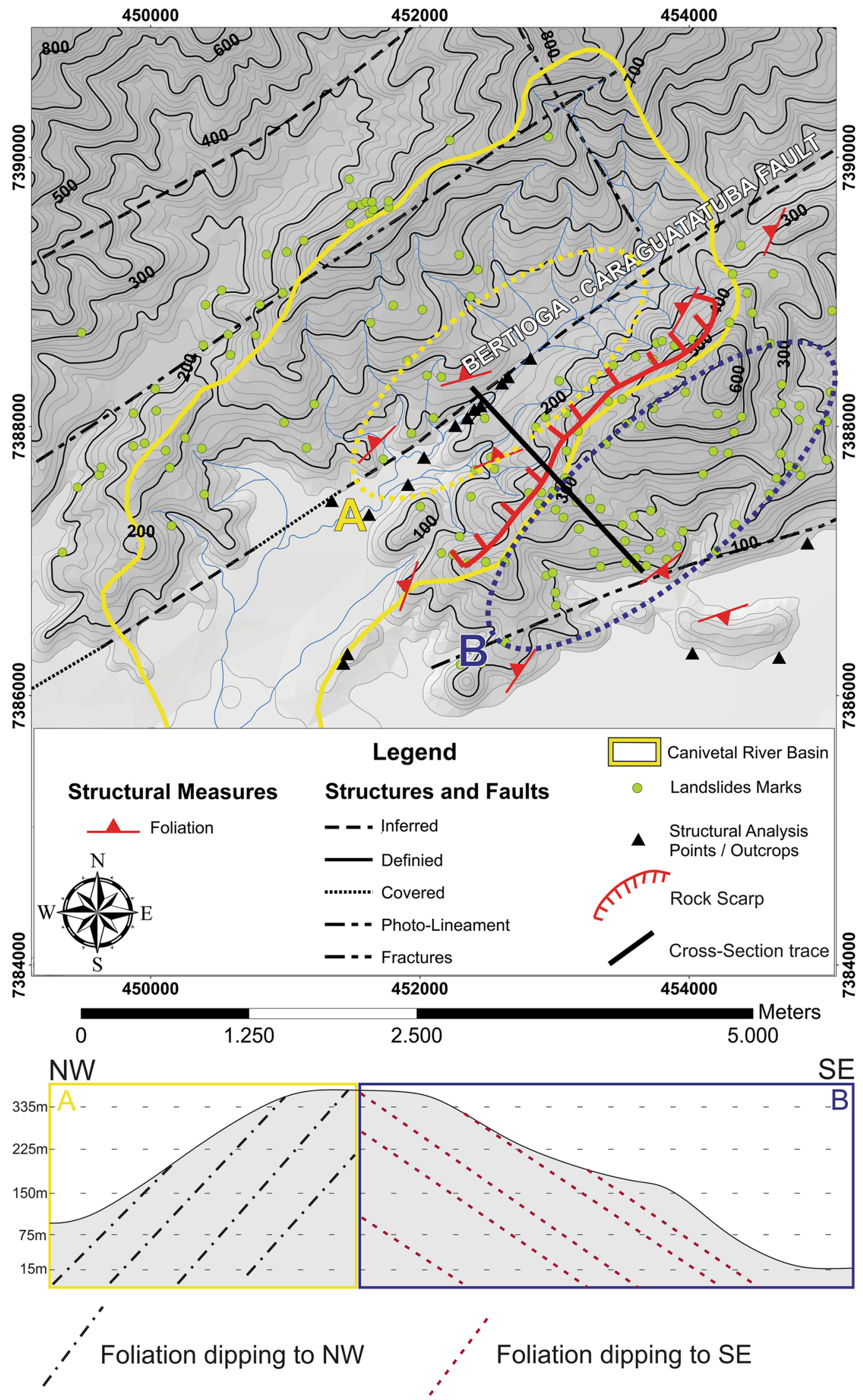
a Number of Landslides Locations

vs.

Mean Declivity (degrees)

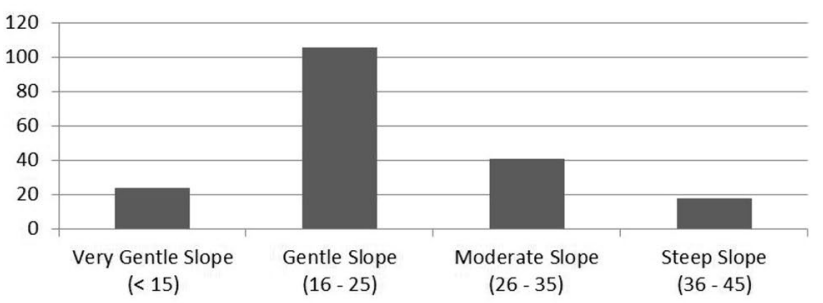

\section{b Number of Landslides Locations}

VS.

Slope Dip Direction

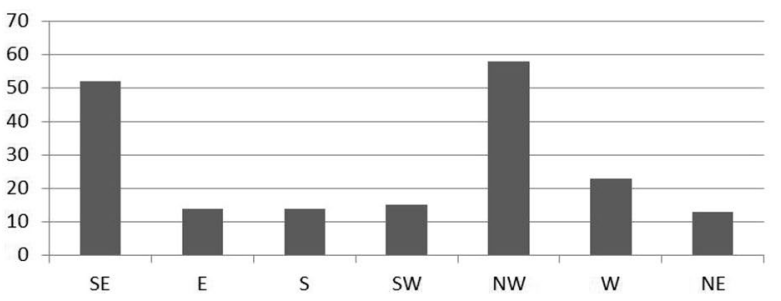

C

Slope Area (\%)

vs.

\section{Slope Dip Direction}

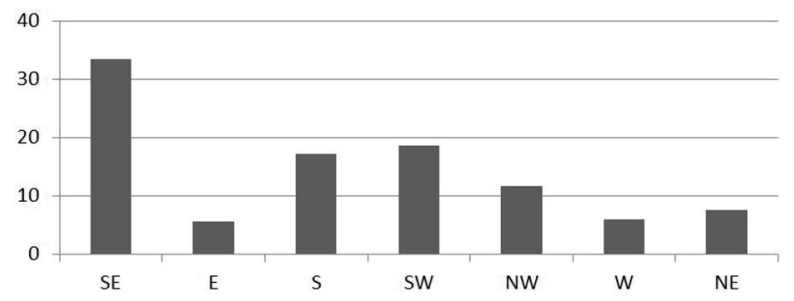

Fig. 10 Bar graph showing number of landslide locations in the study area, versus declivity $\left(^{\circ}\right)(\mathbf{a})$, slope dip direction (b) and area of occurrence of slopes with the same dip direction (c)

low to medium possibility) in NE-SW slopes. This reveals an important consideration: landslides can be controlled by the association of preserved geological structures and kaolinite formation, which follows foliation direction. This setting promotes lateral flow and consequent failing, leading to landslides movements.

A dense structural data could help to analyze more clearly the relation between the geological structures and landslides occurrence. However, for preliminary analyses, in a densely vegetated area where access to outcrops becomes extraordinarily difficult, the number of structural data for kinematic analyses summed with graphs seems to help understand this relation.
Acknowledgements The authors would like to thank the Brazilian research agencies, Coordenação de Aperfeiçoamento de Pessoal de Nivel Superior (CAPES) and Conselho Nacional de Desenvolvimento Científico e Tecnológico (CNPq). The authors would also like to thank the Laboratório de Geologia de Engenharia e Meio Ambiente (GEMA) for technical and scientific support.

\section{References}

Almeida FFM (1974) Fundamentos Geológicos do Relevo Paulista. Universidade de São Paulo, Instituto de Geografia. Boletim do Instituto Geográfico e Geológico, p 99

Avanzi GDA, Giannecchini R, Puccinelli A (2004) The influence of the geological and geomorphological settings on shallow landslides. An example in a temperate climate environment: the June 19, 1996 event in northwestern Tuscany (Italy). Eng Geol 73(3):215-228

Borgomeo E, Hebditch KV, Whittaker AC, Lonergan L (2014) Characterising the spatial distribution, frequency and geomorphic controls on landslide occurrence, Molise Italy. Geomorphology 226:148-161

Brenner RP, Garga VK, Blight GE (1997) Shear strength behaviour and the measurement of shear strength in residual soils. In: Blight GE (ed) Mechanics of residual soils. Balkema Press, Rotterdam, pp 155-220

Bressani LA, Bica AVD, Pinheiro RJB, Rigo ML (2001) Residual shear strenght of some tropical soils from Rio Grande do Sul. Revista Solos e Rochas 24:103-113

Brideau MA, Stead D, Couture R (2006) Structural and engineering geology of the east gate landslide, Purcell Mountains, British Columbia, Canada. Eng Geol 84(3):183-206

Brückl EP (2001) Cause-effect models of large landslides. Nat Hazards 23(2):291-314

Caine JS, Evans JP, Forster CB (1996) Fault zone architecture and permeability structure. Geology 24(11):1025-1028

Campanha GAC, Ens HH, Ponçano EWL (1994) Análise morfotectônica do Planalto do Juqueriquerê, São Sebastião (SP). Braz J Geol 24:32-42

Carvalho CM, Riedel PS (2005) Técnicas de Geoprocessamento Aplicadas ao Estudo da Suscetibilidade a Escorregamentos Translacionais nos Entornos dos Polidutos de Cubatão-SP. In: Anais XII Simpósio Brasileiro de Sensoriamento Remoto, Goiânia-PRBrasil, INPE, pp 2901-2908

Cerri RI, Reis FA, Gramani MF, Giordano LC, Zaine JE (2017) Landslides zonation hazard: relation between geological structures and landslides occurrence in hilly tropical regions of Brazil. Anais da Academia Brasileira de Ciências 89(4):2609-2623

Chieregati LA, Theodorovicz AMG, Theodorovicz A, Menezes RG, Chiodi Filho C, Ramalho R (1982) Projeto folhas Natividade da Serra e Caraguatatuba: Relatório Final. São Paulo. Companhia de Pesquisa de Recursos Minerais, Diretoria da Área de Pesquisas. Superintendência Regional de São Paulo

Clague JJ, Stead D (2012) Landslides: types, mechanisms and modeling. Cambridge University Press, Cambridge

Cruz O (1974) A Serra do Mar e o Litoral na Área de Caraguatatuba - SP: Contribuição à Geomorfologia Litorânea Tropical. Tese de Doutorado, Geografia, Universidade de São Paulo, p 181

Cruz O (1975) Evolução de vertentes nas escarpas da Serra do Mar em Caraguatatuba-SP. Anais da Academia Brasileira de Ciências 47(Supl):474-480

Cruz O (2000) Studies on the geomorphic processes of overland flow and mass movements in the Brazilian geomorphology. Revista Brasileira de Geociências 30(3):504-507 
Cuccuru S, Casini L, Oggiano G, Cherchi GP (2012) Can weathering improve the toughness of a fractured rock? A case study using the San Giacomo granite. Bull Eng Geol Env 71(3):557-567

D'amato Avanzi G, Giannecchini R, Puccinelli A (2004) The influence of the geological and geomorphological settings on shallow landslides. An example in a temperate climate environment: the June 19, 1996 even in northwestern Tuscany (Italy). Eng Geol 73(3-4):215-228

Dias HC, Dias VC, Vieira BC (2016) Landslides and morphological characterization in the Serra do Mar, Brazil. In: Aversa S, Cascini L, Picarelli L, Scavia C (eds.) Landslides and engineered slopes. Experience, theory and practice. Proceedings of the 12th international Symposium on Landslides, pp 831-836

DNPM/CPRM (1991) Mapa Geológico da Folha Pico do Papagaio 1:50000. Projeto de Integração Geológica da Região Metropolitana de São Paulo

Fernandes NF, Guimarães RF, Gomes RA, Vieira BC, Montgomery DR, Greenberg H (2004) Topographic controls of landslides in Rio de Janeiro: field evidence and modeling. Catena 55(2):163-181

Ferreira MV, Riedel PS, Lopes ESS, Merino ER (2008) Comparação entre diferentes critérios para elaboração de Mapas de Suscetibilidade aos escorregamentos. Exemplo do município de Cubatão, Serra do Mar Paulista. Revista Brasileira de Cartografia 60:385-400

Fúlfaro VJ, Ponçano WL, Bistrichi CA, Stein DP (1976) Escorregamentos de Caraguatatuba: expressão atual, e registro na coluna sedimentar da planície costeira adjacente. In: Congresso Brasileiro de Geologia de Engenharia, Rio de Janeiro. vol 2, pp 341-350

Furian S, Barbiero L, Boulet R (1999) Organisation of the soil mantle in tropical southeastern Brazil (Serra do Mar) in relation to landslides processes. Catena 38(1):65-83

Gobbi F, Bernardes JA, Bica AVD, Bressani LA, Flores JAA, Azambuja E (2005) Estudo da resistência ao cisalhamento do solo residual de gnaisse Porto Alegre, in: COBRAE, 4, Salvador: ABMS, vol I, pp 173-181

Gokceoglu C, Sonmez H, Ercanoglu M (2000) Discontinuity controlled probabilistic slope failure risk maps of the Altindag (settlement) region in Turkey. Eng Geol 55(4):277-296

Gratchev I, Shokouhi A, Kim DH, Stead D, Wolter A (2013) Assessment of rock slope stability using remote sensing technique in the Gold Coast area, Australia. In: 18th Southeast Asian geotechnical \& inaugural AGSSEA conference

Guerra AJT, Fullen MA, Jorge MDCO., Bezerra JFR, Shokr MS (2017) Slope processes, mass movement and soil erosion: a review. Pedosphere 27(1):27-41

Hasui Y (2012) Sistema Orogênico Mantiqueira. Geologia do Brasil. Beca, São Paulo, pp 331-610

Hasui Y et al. (1978) Geologia da região administrativa 3 (Vale do Paraíba) e parte da Região Administrativa 2 (Litoral) do estado de São Paulo: Mapa Geológico em escala 1: 200.000. Instituto de Pesquisas Tecnológicas (IPT. Monografias, 1), Publicação IPT n. 1106 (unpublish)

Heilbron M et al. (2004) Província Mantiqueira. In: Mantesso-Neto V, Bartorelli A, Carneiro CD, Brito-Neves BB (eds) Geologia do continente sul-americano: evolução da obra de Fernando Flávio Marques de Almeida (pp 203-235). Beca, São Paulo

Hoek E, Bray JD (1981) Rock slope engineering. CRC Press, Boca Raton

Instituto Florestal (2007) Inventário Florestal da Vegetação Natural do Estado de São Paulo. Regiões Administrativas de São José dos Campos (Litoral), Baixada Santista e Registro. São Paulo (Brazil), Instituto Florestal, p 140

IPT-Instituto de Pesquisas Tecnológicas (1988) Estudos da instabilização de encostas da Serra do Mar na Região de Cubatão, objetivando a caracterização do fenômeno "corrida de lama" e a prevenção de seus efeitos. São Paulo: Relatório IPT no. 25258

IPT-Instituto de Pesquisas Tecnológicas (2000) Diagnóstico da situação atual dos recursos hídricos da Unidade de Gerenciamento dos Recursos Hídricos do Litoral Norte: relatório final. São Paulo: Relatório no. 46172

Irfan TY, Woods NW (1988) The influence of relict discontinuities on slope stability in saprolitic soils. In: International conference on geomechanics in tropical soils, 2nd, vol 1, 1988, Singapore

Kojima S, Nagata H, Yamashiroya SI, Iwamoto N, Ohtani T (2015) Large deep-seated landslides controlled by geologic structures: prehistoric and modern examples in a Jurassic subduction-accretion complex on the Kii Peninsula, central Japan. Eng Geol 186:44-56

Lacerda WA, Silveira GC (1992) Características de resistência ao cisalhamento e de compressibilidade dos solos residuais e coluvionares da encosta do Soberbo, RJ. In: COBRAE. ABMS/ ABGE, 1, Rio de Janeiro, pp 445-461

Listo FDLR., Vieira BC (2015) Influência de Parâmetros Geotécnicos e Hidrológicos na Previsão de Áreas Instáveis a Escorregamentos Translacionais Rasos Utilizando o Modelo Trigrs. Revista Brasileira de Geomorfologia 16

Lopes ESS, Riedel PS, Bentz CM, Ferreira MV, Naleto JLC (2007) Inventário de escorregamentos naturais em banco de dados geográfico-análise dos fatores condicionantes na região da Serra de Cubatão-SP. In: XIII Simpósio Brasileiro de Sensoriamento Remoto, Florianópolis, pp 2785-2796

Luzon PK, Montalbo K, Galang J, Sabado JM, Escape CM, Felix R, Lagmay AMF (2016) Hazard mapping related to structurally controlled landslides in Southern Leyte, Philippines. Nat Hazards Earth Syst Sci 16:875-883

Marcelino EV (2003) Mapeamento de áreas susceptíveis a escorregamento no município de Caraguatatuba (SP), usando técnicas de sensoriamento remoto. Dissertação de Mestrado. São José dos Campos, Instituto Nacional de Pesquisas Espaciais (INPE), p 228. (unpublished)

Margielewski W (2006) Structural control and types of movements of rock mass in anisotropic rocks: case studies in the Polish Flysch Carpathians. Geomorphology 77:47-68

Mendes RM (2008) Estudo das Propriedades Geotécnicas de Solos Residuais Não Saturados de Ubatuba (SP). PhD thesis. Escola Politécnica da Universidade de São Paulo

Modenesi MC, Toledo MC (1993) MorfogÊnese quaternária e intemperismo: Colúvios do planalto de Itatiaia. Revista do Instituto Geológico de São Paulo, pp 45-53

Moura CAD, Mattos JTD, Jiménez-Rueda JR (2012) Análise de fraturamentos para determinação de áreas instáveis na faixa de dutos Osvat/Osplan - São Sebastião, em São Paulo. Revista Brasileira de Geociências 42:585-596

Nieble CM, Guidicini G (1984) Estabilidade de Taludes Naturais e de Escavação. Editora Edgard Blücher. ${ }^{a}$. Ed. São Paulo

Park HJ, Lee JH, Kim KM, Um JG (2016) Assessment of rock slope stability using GIS-based probabilistic kinematic analysis. Eng Geol 203:56-69

Parzen E (1962) On estimation of a probability density function and mode. Ann Math Stat 33:1065-1076

Peruccacci S, Brunetti MT, Luciani S, Vennari C, Guzzetti F (2012) Lithological and seasonal control on rainfall thresholds for the possible initiation of landslides in central Italy. Geomorphology 139-140, p. 79-90

Ponçano WL, Carneiro CDR, Bristrichi CA, Almeida FFM, Prandini FL (1981) Notícia Explicativa do Mapa Geomorfológico do Estado de São Paulo, 5. São Paulo, IPT, Monografias, p 94

Prado J, Hirai RY (2011) Checklist das Licófitas e Samambaias do Estado de São Paulo, Brasil. Biota Neotropica 11, pp 161-190 
Ramos VM, Guimarães RF, Redivo AL, Gomes RAT, Fernandes NF, Carvalho Júnior OA (2002) Aplicação do modelo SHALSTAB, em ambiente ArcView, para o mapeamento de áreas susceptíveis a escorregamento raso na Região do Quadrilátero Ferrífero (MG). Espaço e Geografia 5:49-67

Rocscience (2010) Dips users manual. Rocscience Inc., Toronto

Roering JJ, Kirchner JW, Dietrich WE (2005) Characterizing structural and lithologic controls on deep-seated landsliding: implications for topographic relief and landscape evolution in the Oregon Coast Range, USA. Geol Soc Am Bull 117(5-6):654-668

Ross JLS, Moroz IC (1997) Mapa Geomorfológico do Estado de São Paulo. Laboratório de Geomorfologia. Departamento de Geografia - FFLCH-USP/Laboratório de Cartografia Geotécnica - Geologia Aplicada - IPT/FAPESP (Fundação do Amparo à Pesquisa do Estado de São Paulo), São Paulo

Selby MJ (1993) Hillslope materials and processes, 2nd edn. Oxford University Press, Oxford

Seluchi ME, Chou SC (2009) Synoptic patterns associated with landslide events in the Serra do Mar, Brazil. Theor Appl Climatol 98(1-2):67-77

Shuib MK, Taib SH, Abdull M (2006) Discontinuity controlled cut-slope failures on weathered low grade metamorphic rocks along the east-west highway, Grik to Jeli. Geol Soc Malays Bull $52: 43-53$

Siddique T, Alam MM, Mondal MEA, Vishal V (2015) Slope mass rating and kinematic analysis of slopes along the national highway-58 near Jonk, Rishikesh, India. J Rock Mech Geotech Eng 7(5):600-606

Silva AS, Guerra AJ, Polivanov H, Fullen MA (2016) Soil structural indicators of hillslope destabilization in the Serra do Mar mountain range (Rio de Janeiro State, Brazil). Nat Hazards 81(2):1177-1191

Smith JV (2015) A new approach to kinematic analysis of stressinduced structural slope instability. Eng Geol 187:56-59

Souza Neto JB, Lacerda WA, Coutinho RQ (2001) Variabilidade nos parâmetros geotécnicos de alguns solos residuais brasileiros. COBRAE, III, Rio de Janeiro, pp 305-315

Souza Pinto C, Nader JJ (1991) Ensaios de laboratório em solos residuais. In: Seminário de Engenharia de Fundações Especiais, 2. ABEF/ABMS, Anais... São Paulo, pp 166-202
Sturzenegger M, Stead D (2009) Quantifying discontinuity orientation and persistence on high mountain rock slopes and large landslides using terrestrial remote sensing techniques. Nat Hazards Earth Syst Sci 9(2):267-287

Vatanpour N, Ghafoori M, Talouki HH (2014) Probabilistic and sensitivity analyses of effective geotechnical parameters on rock slope stability: a case study of an urban area in northeast Iran. Nat Hazards 71(3):1659-1678

Veloso HP, Rangel Filho ALR, Lima JCA (1991) Classificação da vegetação brasileira, adaptada a um sistema universal. Ministério da Economia, Fazenda e Planejamento, Fundação Instituto Brasileiro de Geografia e Estatística, Diretoria de Geociências, Departamento de Recursos Naturais e Estudos Ambientais

Vervloet R, Ross J (2012) Revisão dos conhecimentos sobre o relevo do Planalto Atlântico brasileiro: incógnitas que ainda persistem. Revista do Departamento de Geografia 23:187-216

Vieira BC, Gramani MF (2015) Serra do Mar: The most "tormented" relief in Brazil, in: Vieira CB, Salgado R.A.A., Santos C.L.J. (eds) Landscapes and landforms of Brazil. Springer, Berlin, pp 285-297

Vieira BC, Fernandes NF, Filho OA (2010) Shallow landslide prediction in the Serra do Mar, São Paulo, Brazil. Nat Hazards Earth Syst Sci 10(9):1829-1837

Von Ruette J, Lehmann P, Or D (2014) Effects of rainfall spatial variability and intermittency on shallow landslide triggering patterns at a catchment scale. Water Resour Res 50:7780-7799

Wiegand C, Kringer K, Geitner C, Rutzinger M (2013) Regolith structure analysis - a contribution to understanding the local occurrence of shallow landslides (Austrian Tyrol). Geomorphology 183:5-13

Wolle CM, Carvalho CS (1978) Deslizamentos em encostas na Serra do Mar, Brasil. Revista Solos e Rochas, v.12, pp 27-36

Wyllie D, Mah C (2004) Rock slope engineering: civil and mining, 4th edn. Spon Press, London, pp 129-217

Yamasaki S, Chigira M (2011) Weathering mechanisms and their effects on landsliding in pelitic schist. Earth Surf Process Landf 36:481-494

Zêzere JL, Trigo RM, Trigo IF (2005) Shallow and deep landslides induced by rainfall in the Lisbon region (Portugal): assessment of relationships with the North Atlantic Oscillation. Nat Hazards Earth Syst Sci 5:331-344 